Pesq. Vet. Bras. 36(11):1127-1131, novembro 2016 DOI: $10.1590 / \mathrm{S} 0100-736 \mathrm{X} 2016001100012$

\title{
Comparative anatomy of the gluteal muscles of Sapajus libidinosus ${ }^{1}$
}

\author{
Nayane Peixoto Soares ${ }^{2}$, Vanessa de Souza Vieira², Dayane Kelly S. Pereira ${ }^{3}$, \\ Fabiano Campos Lima ${ }^{3}$, Eugênio Gonçalves Araújo ${ }^{2}$ and Kleber Fernando Pereira ${ }^{3 *}$
}

\begin{abstract}
Soares N.P., Vieira V.S., Pereira D.K.S., Lima F.C., Araújo E.G. \& Pereira K.F. 2016 Comparative anatomy of the gluteal muscles of Sapajus libidinosus. Pesquisa Veterinária Brasileira 36(11):1127-1131. Laboratório de Anatomia Humana e Comparativa, Curso de Ciências Biológicas, Universidade Federal de Goiás, Regional Jataí, BR-364 Km 192, Setor Parque Industrial, Jataí, G0 75800-000, Brazil. E-mail: kpereiraufg@gmail.com

New World primates Sapajus sp. unexpectedly display cognitive aspects, tool use, social behavior, memory and anatomical aspects similar to Old World primates, such as chimpanzees and baboons. Convergent evolutionary aspects must have occurred between Sapajus and Old World primates and should be verified not only in terms of behavior analysis, but also of anatomical structure. The pelvic region can provide data for evolutionary verification trends, since taking standing position is one of the characteristics associated to the use of tools by early humans and pongids. We used eight specimens of Sapajus libidinosus to describe the deep muscular structure of the pelvis. Unlike humans, the gluteus medius muscle in S. libidinosus is completely covered by the gluteus maximus and elongated as compared to humans and chimpanzees, putatively by the elongated pelvis of S. libidinosus. Considering origin and insertion, the gluteus maximus muscle resembles more its counterpart in baboons than in humans and chimpanzees, since this muscle in baboons is associated to semibiped posture and to the tail. Gluteus minimum, piriformis, superior gemellus, internal shutter, gemellus and lower square muscles are positioned in this order in relation to the cranial-caudal axis, with all of its tendons converging for a common insertion in the greater trochanter. The muscles of the gluteal region of $S$. libidinosus are similar to the baboon, especially regarding the gluteus maximus, which points to the evolutionary kinship of these animals.
\end{abstract}

INDEX TERMS: Gluteal muscles, Sapajus libidinosus, bipedalism, capuchin, primates.

RESUMO.- [Anatomia comparativa dos músculos da região glútea de Sapajus libidinosus.] Os Sapajus sp apresentam aspectos cognitivos, uso de ferramentas, comportamento social e memória, além de aspectos anatômicos, similares à primatas do Velho Mundo, como chimpanzés e babuínos, fatos inesperados para estes animais, que são primatas do Novo Mundo. Aspectos evolutivos convergentes devem ter ocorrido entre Sapajus e primatas do Velho Mundo que devem ser verificados não somente em termos

\footnotetext{
${ }^{1}$ Received on June 1, 2016.

Accepted for publication on July 5, 2016.

${ }^{2}$ Laboratório Multiusuário de Cultura Celular, Escola de Veterinária e Zootecnia (EVZ), Universidade Federal de Goiás (UFG), Avenida Esperança s/n, Campus Samambaia, Goiânia, GO 75800-000, Brazil

${ }^{3}$ Laboratório de Anatomia Humana e Comparativa, Curso de Ciências Biológicas, UFG, Regional Jataí, BR-364 Km 192, Setor Parque Industrial, Jataí, GO 75800-000, Brazil. *Corresponding author: kpereiraufg@gmail.com
}

de análise do comportamento, mas da estrutura anatômica. A região pélvica pode fornecer dados para a verificação de tendências evolucionárias, pois assumir a posição bípede é uma das características associadas ao uso de ferramentas pelos humanos primitivos e pongídeos. Para descrever a estrutura muscular profunda da pelve, foram utilizados oito espécimes de Sapajus libidinosus. 0 músculo glúteo médio em S. libidinosus, diferente de humanos, é totalmente recoberto pelo glúteo máximo, é alongado em relação aos humanos e chimpanzés, putativamente pela pelve alongada dos $S$. libidinosus. 0 músculo glúteo máximo se assemelha, considerando origem e inserção mais aos babuínos do que em humanos e chimpanzés, uma vez que em babuínos esse músculo está associado à postura semibípede e à cauda. Os músculos glúteo mínimo, piriforme, gêmeo superior, obturador interno, gêmeo inferior e quadrado estão posicionados nesta ordem em relação ao eixo crânio-caudal com 
todos seus tendões convergindo para uma inserção comum no trocânter maior. Os músculos da região glútea de $S$. libidinosus são semelhantes ao babuíno principalmente no que se refere ao músculo glúteo máximo, o que reflete o parentesco evolutivo desses animais.

TERMOS DE INDEXAÇÃO: Músculos da região glútea, Sapajus libidinosus, bipedalismo, macaco-prego, primatas.

\section{INTRODUCTION}

Primates of the Sapajus gender are widely distributed throughout the Americas, dwelling in several different niches. In Brazil, these monkeys are common in tropical, subtropical and riparian forests, as well as in savannas and semi-arid areas (Lopes 2004, Vilanova et al. 2005). It belongs to the Platyrrhini infra-order, covering the New World (Neotropical) monkeys, the Cebidae family and, previously, to the genus Cebus (Fragaszy et al. 2004, Soares et al. 2014). Sapajus primates have undergone successive systematic and taxonomic changes. Rylands et al. (2000) proposed that the previously named Cebus apella libidinosus should be classified into the genus Cebus, species Cebus libidinosus (C. libidinosus). However, Lynch-Alfaro et al. (2012a), based on an extensive review of the morphological, genetic, behavioral, ecological and biogeographical aspects (Lynch-Alfaro et al. 2012b, Vieira 2013, Wright et al. 2014, Bacalhao et al. 2016) re-classified the capuchin monkey into the Sapajus genus and Sapajus libidinosus species.

Their ability to handle tools to obtain food and engage in fun activities are observed both in captivity and in the wild (Breseida \& Ottoni 2001, Resende \& Ottoni 2002). Capuchins display social habits such as food division among group members, which is similar to humans, chimpanzees and orangutans (Waal 2005, Meulman et al. 2012). They are well adapted to arboreal life, using their forelimbs to move with the aid of their tails, which are semi-prehensile and can be further used to grasp an object, in addition to supporting the animal's weight (Fragaszy et al. 2004). Such aspects corroborate the choice of the monkeys as a model for anatomical and behavioral studies (Marin et al. 2009). The knowledge of new world primates' anatomy should provide data for a better understanding of evolution, phylogeny and taxonomy of this animal group (Aversi-Ferreira et al. 2010, Lynch-Alfaro et al. 2014). Another purpose is to assist veterinarians with anatomical data for clinical and surgical procedures, since capuchins are frequently demand veterinary care after car accidents or electrocution (Aversi-Ferreira et al. 2011a, Lima et al. 2016).

Comparative anatomical studies performed in S. libidinosus that listed and described muscles, nerves and vessels of the forelimb (Aversi-Ferreira et al. 2006, Aversi-Ferreira et al. 2007, Marin et al. 2009, Aversi-Ferreira et al. 2010, 2014a, 2014b) were used to place Sapajus libidinosus evolutionarily close to chimpanzees regarding the the use of tools (Marin et al. 2009, Aversi-Ferreira et al. 2011b). Furthermore, capuchins were related to baboons and chimpanzees in studies on the nerves, vessels and muscles of pelvic limb, pelvis and dura-mater (Aversi-Ferreira et al. 2011, 2013, 2014a,b,c, Abreu et al. 2012, Pereira et al.
2013, Soares et al. 2014, Vieira et al. 2015). However, it is imperative to obtain further information on the pelvis anatomy of S. libidinosus, in order to confirm the evolutionary closeness to other primates.

The aimed was to study the gluteal muscles, in the pelvis, as well as its origin and insertion of Sapajus libidinosus (formerly known as Cebus libidinosus) and these results compared with the literature on the anatomy of humans, chimpanzees and baboons associated to behavioral and evolutionary data.

\section{MATERIALS AND METHODS}

We used eight adult, lesion-free Sapajus libidinosus specimens of different ages and genders ( 2 males and 1 female with 1 to $3 \mathrm{Kg}$ of body weight). The animals were donated by the Brazilian Institute of the Environment (IBAMA) and deposited in the anatomical collection of the Federal University of Goiás, Catalão campus. This study was approved by the Ethics and Research committee (COEP-UFG Case no. 81/2008, IBAMA authorization no. 15275).

All the animals were weighed and perfused through the abdominal aorta with 601-A latex (Dupot) mixed with red dye solution diluted in ammonium hydroxide, immersed in water at room temperature for 10-12 hours and fixed by perfusion of the femoral vein with $10 \%$ formaldehyde solution with $5 \%$ of glycerin. The specimens were stored in 10\% formaldehyde solution in a closed opaque recipient. The muscles were dissected and documented with a digital camera (Cannon, 14 mega pixels). The description of the structures was based on humans (Gray 2000) and other primates (Swindler \& Wood 1973).

\section{RESULTS AND DISCUSSION}

The origins and insertions of the gluteal region muscles of Sapajus libidinosus are described in Table 1. The muscles observed were gluteus maximus, gluteus medius, gluteus minimus, piriformis, superior gemellus, internal shutter, inferior gemellus, quadratus femoris and shutter externus.

The gluteus maximus muscle (Fig.1) originates from: (1) the posterior side of the iliac crest, from the anterior superior iliac spine to the posterior superior iliac spine; (2) the gluteal aponeurosis; and posterolaterally, (3) at the sacrum and the first caudal vertebrae. Its fibers converge laterally, in a parallel and oblique fashion, towards the iliotibial tract and femur. The superficial fibers insert into the tensor fascia latae muscle, the iliotibial tract and at the proximal and middle thirds of the femur, between the vastus lateralis and adductor magnus muscles. A major portion of the gluteus maximus muscle is on thigh side. A variation in one of the insertions was observed in a specimen, which occurred in the middle third of the femur alone.

The gluteus maximus muscle in S. libidinosus is similar to its counterpart in the baboon (Papio) regarding both origin and insertion, but is different in man (Homo) and chimpanzee (Pan). The fusing of some fibers of this muscle to the tensor fascia latae muscle is similar in the baboon and chimpanzee, in which both muscles merge. In non-human primates, the gluteus maximus is situated laterally to the thigh and acts as its abductor (Swindler \& Wood 1973); the same feature was observed in S. libidinosus, although the capuchin has a more elongated pelvis as compared to man, resulting in a lateralized, longer muscle. In humans, the glu- 
Table 1. The gluteal region muscles of Sapajus libidinosus

\begin{tabular}{|c|c|c|}
\hline Muscle & Origin & Insertion \\
\hline Gluteus superficialis & $\begin{array}{l}\text { Posterior surface of the crista iliaca; } \\
\text { aponeurosis glutea; sacrum } \\
\text { and vertebrae caudales }\end{array}$ & $\begin{array}{l}\text { Muscle tensor fasciae latae; iliotibial } \\
\text { tractus and in the body of the } \\
\text { femur (proximal and middle) }\end{array}$ \\
\hline Gluteus medius & $\begin{array}{l}\text { Sacrum and posterior } \\
\text { surface of the crista iliaca }\end{array}$ & $\begin{array}{l}\text { Trochanter major } \\
\text { of the femur }\end{array}$ \\
\hline Gluetus porfundus & Ala ossis ilii & Trochanter major of the femur \\
\hline Piriformis & $\begin{array}{l}\text { Facies pelvina of the sacrum } \\
\text { and incisura ischiadica major }\end{array}$ & Trochanter major of the femur \\
\hline Gemelli cranialis & Spina ischiadica minor & $\begin{array}{l}\text { Trochanter major of the femur, near the } \\
\text { obturatorius internus tendon }\end{array}$ \\
\hline Obturatorius internus & $\begin{array}{l}\text { Ramus caudalis ossis pubis } \\
\text { and ramus ossis ischii }\end{array}$ & $\begin{array}{l}\text { Trochanter major } \\
\text { of the femur }\end{array}$ \\
\hline Gemelli caudalis & Tuber ischiadicum & $\begin{array}{l}\text { Trochanter major of the femur, near } \\
\text { the obturatorius internus tendon }\end{array}$ \\
\hline Quadratus femoris & Tuber ischiadicum & Tuberculum quadratus of the femur \\
\hline Obturatorius externus & Foramen obturatum circunference & Fossa trochanterica of the femur \\
\hline
\end{tabular}

teus maximus acts as extensor of the thigh and has a larger volume, similarly to other muscles of this group, a feature that evolutionarily resulted in shortening and widening of the ileum, narrowing the distance between the sacroiliac joint and the hip joint, as well as enlargement of the pelvis joint and the sacrum. The large volume, powerful force of extension and different shape from other quadrupeds that changed the bone structure of the pelvis in humans are primarily responsible for true human bipedal stance. In the case of S. libidinosus, its similar muscles to Papio, is compatible to its semi biped posture (Ankel-Simons 2000). $S$. libidinosus has a semi biped posture, but its gluteus maximus is equivalent to the muscle in quadrupeds, Papio and partially in Pan, performing abduction of the thigh and preventing the capuchin from taking a real bipedal posture.

The gluteus medius (Fig.2) is deep and fully covered by the gluteus maximus. The gluteus medius originates at the sacral vertebrae and at the posterior face of the iliac crest, from the anterior superior iliac spine to the greater sciatic notch. Its fibers follow in a parallel and oblique sort towards the greater trochanter, where it inserts through short tendons. The proximal third of the gluteus medius is covered by the gluteal aponeurosis.

The gluteus medius muscle in S. libidinosus, diversely from Homo, is completely covered by the gluteus maximus muscle and is elongated as compared to the same muscle in Homo and Pan. This feature may be an evolutionary consequence of the more elongated aspect of Sapajus pelvis.

The gluteus minimus (Fig.3) locates deeply to both gluteus and originates from the middle third of the pelvic bone, at ilium wing. Its parallel and oblique fibers converge to a tendon that inserts into the greater trochanter. The triangular gluteus minimus the smallest of the gluteus.

The gluteus minimus and other muscles of this region (piriform, gemellus, square femur, internal and external shutter) have, in general, similar origin and insertion in $S$. libidinous, baboons (Papio), chimpanzees (Pan) and man (Homo) (Swindler \& Wood 1973), but can vary in size.

The piriformis muscle (Fig3) is located immediately lateral-inferior to the gluteus minimus muscle. It is a triangular, pear-shaped muscle, smaller than the gluteus minimus,



Fig.1. Gluteus maximums muscle of Sapajus libidinosus, left side view. Origin of Gluteus maximus (1); Insertion of the Gluteus maximus (2). GMX = Gluteus maximus; $\mathrm{TFL}=$ Tensor Fascia latae; VL = Side Vastus; LF = Femoral biceps; TIT =- Iliotibial tract.



Fig.2. Gluteus medius muscle of Sapajus libidinosus, right dorsolateral view (Arrow $=$ Insertion of the Gluteus medius). GMd = Gluteus medius; $\mathrm{GMx}=$ Gluteus maximus; $\mathrm{GMi}=$ Gluteus min; $\mathrm{NI}=$ Sciatic nerve 


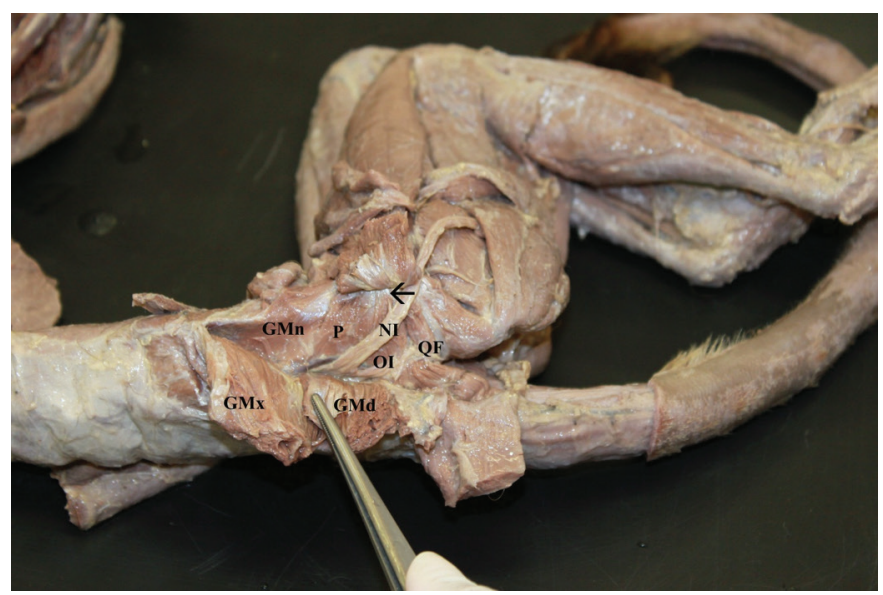

Fig.3. Muscles of the gluteus region of Sapajus libidinosus, right dorsolateral view (Arrow $=$ Common insertion of the muscle group (Gluteus min [GMN], Piriformis [P], Superior gemellus, Internal shutter [HI], Lower gemellus, Square Femur [FF]); NI = Sciatic Nerve; GMX = Gluteus Maximus; GMD = Eastern gluteus.

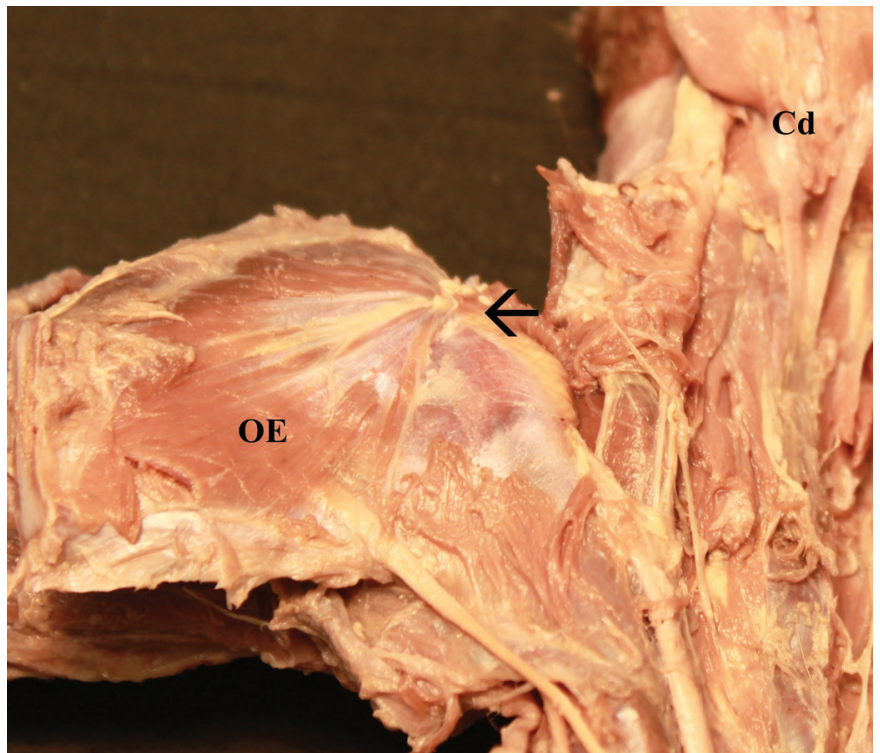

Fig.4. External shutter muscle (OE) of Sapajus libidinosus, left latero-ventral view.

but larger compared to the others described below. It originates in the pelvic surface of the sacrum and the greater sciatic notch and inserts on the greater trochanter.

The top twin muscle is originated at the lower ischial spine and inserts in the greater trochanter of the femur, along the tendon of the internal shutter muscle. It is a small triangular muscle.

The internus shutter muscle (Fig.3) originates at the lower branch of the pubic bone and the ischium bone branch, and inserts at the greater trochanter of the femur. Along the piriformis, superior gemellus and gluteus minimus, it is completely covered by the gluteus medius and gluteus maximus muscles. The sciatic nerve crosses the posterior part of this muscle. It is followed by the lower gemellus.

The lower gemellus originates from the isquiatic tuberosity and inserts at the femur greater trochanter, along the internal shutter muscle tendon. It is conspicuously thinner than the upper gemellus. It is followed by the last muscle of group, the square of the femur.

The square muscle of the femur (Fig.3) originates at the isquiatic tuberosity and inserts at the square tubercle of femur. The venter is rectangular and the muscle is longer as compared to the lower gemellus.

The gluteus minimum, piriformis, superior gemellus, internal shutter, square bottom and gemellus muscles are positioned in this order in relation to the craniocaudal axis, with all your tendons converging to a common insertion into the greater trochanter. The tendon of the square muscle of the femur is the shortest.

The sciatic nerve leaves the pelvis and crosses the entire muscle group to enter the thigh through the greater sciatic foramen, above the square muscle of the femur, through the lower gemellus. However, in one specimen, there was a variation in the path of this nerve, which was positioned superiorly and medially as compared to the others. There was also a specimen in which the sciatic nerve branched into tibial and common peroneal nerve at the gluteus minimum muscle, a feature that usually occurs in the thigh. After branching, these nerves leave the pelvis along the dorsal surface of the muscle group previously desccribed.

The external shutter muscle (Fig.4) originates at the shutter foramen circumference and the shutter membrane and inserts in the intertrochanteric fossa of the femur. It is a triangular flat muscle, that covers the entire pubic area inner face, including the shutter foramen.

The path of the sciatic nerve in Sapajus, as well as the branching variation described, is identical to man. However, as the nerve leaves the pelvis, it runs between the square muscle of the femur and the upper gemellus in $S$. libidinosus, while in humans the sciatic passes below the piriform (Gray 2000). This characteristic also differs in dogs and cats, as observed by Guimarães et al. (2005), that reported the passage of this nerve between the piriformis and deep gluteus. Therefore, protocols of intramuscular injections and other medical and surgical procedures can be performed in this region, like in other animals (Pereira et al. 2011). Nevertheless, according to Guimarães et al. (2005), these procedures should be executed with special care to avoid damage to this important motor nerve.

The similarities to other primates, particularly to man, in the origins, insertions and topography of the S. libidinosus pelvis inner side muscle group, e.g. the gluteus minimus, piriformis, superior gemellus, internal shutter, lower gemellus, square and external shutter, have already been described. The exception, as previously mentioned, is the path of the main nerve of this region, the sciatic. Likewise, another anatomical description for Sapajus muscles and the muscles of the shoulder, reported by Lima et al. (2013) were similar in all aspects to the same muscle group in humans.

It can be concluded that the muscles of the gluteal region in S. libidinosus are similar to the baboon, especially the gluteus maximus muscle, which points to the evolutionary relation of these animals, belonging to the same infra-order (Platyrrhini) and sharing the semibiped posture. 


\section{REFERENCES}

Abreu T., Pfrimer G., Aversi-Ferreira R.A.G.M.F., Brandão L.D., Maior R.S., Nishijo H. \& Aversi-Ferreira T.A. 2012. Comparative anatomical study of the leg's nerves of Cebus (barbed capuchins) with baboons, chimpanzees and modern humans. Pesq. Vet. Bras. 32:113-117.

Ankel-Simons F. 2000. Primate Anatomy: an introduction. Elsevier Academic Press, Massachusetts. 752p.

Aversi-Ferreira T.A., Silva M.S.L., Paula J.P. \& Mata J.R. 2006. Anatomia comparativa entre os músculos extensores do antebraço de Cebus libidinosus com humanos e outros primatas. Revta Eletrôn. Farmácia 3:13-15.

Aversi-Ferreira T.A., Pereira-de-Paula J., Prado L.Y.C., Lima-e-Silva M.S. \& Mata J.R. 2007. Anatomy of the shoulder and arm muscles of Cebus libidinosus. Braz. J. Morpholol. Sci. 24:63-74.

Aversi-Ferreira T.A., Diogo R., Potau J.M., Bello G., Pastor J.F. \& Ashraf-Aziz M. 2010. Comparative anatomical study of the forearm extensor muscles of Cebus libidinosus (Rylands et al., 2000; Primates, Cebidae), modern humans, and other primates, with comments on primate evolution, phylogeny, and manipulat ory behavior. Anat. Rec. 293:20562070.

Aversi-Ferreira R.A.G.M.F., Marin K.A., Silva C.F.O. \& Aversi-Ferreira T.A. 2011a. Comparative anatomy of the thigh nerves of Cebus libidinosus (Rylands et al. 2000). Pesq. Vet. Bras. 31:1-6.

Aversi-Ferreira T.A., Maior R.S., Carneiro-e-Silva F.O., Aversi-Ferreira R.A.G.M.F., Tavares M.C., Nishijo H. \& Tomaz C. 2011b. Comparative anatomical analyses of the forearm muscles of Cebus libidinosus (Rylands et al. 2000): manipulatory behavior and tool use. Plos One 6:1-8.

Aversi-Ferreira R.A.G.M.F., Abreu T., Pfrimer G.A., Silva S.F., Ziermann J.M., Carneiro-e-Silva F.O., Tomaz C., Tavares M.C.H., Maior R.S. \& Aversi-Ferreira, T.A. 2013. Comparative anatomy of the hind limb vessels of the bearded capuchins (Sapajus libidinosus) with apes, baboons, and Cebus capucinus: with comments on the vessels' role in bipedalism. Biomed. Res. Int. 2013:1-15.

Aversi-Ferreira R.A.G.M.F., Maior R.S., Aziz A., Ziermann J.M., Nishijo H., Tomaz C., Tavares M.C.H. \& Aversi-Ferreira T.A. 2014a. Anatomical analysis of thumb opponency movement in the capuchin monkey (Sapajus $s p$ ). Plos One 9:e87288.

Aversi-Ferreira R.A.G.M.F., Bretas R.V., Maior R.S., Davaasuren M., Paraguassú-Chaves C.A., Nishijo H. \& Aversi-Ferreira T.A. 2014b. Morphometric and Statistical Analysis of the Palmaris Longus Muscle in Human and Non-Human Primates. Biomed. Res. Int. 2014:1-6.

Aversi-Ferreira R.A.G.M., Vieira V.S., Tomaz C.A.B. \& Aversi-Ferreira T. 2014c. Comparative anatomy of the pelvic vessels in the bearded capuchin (Sapajus libidinosus) with baboons, apes and modern humans. Folia Primatologica 85:252-264.

Bacalhao M.B.M., Firmino M.O., Siqueira R.A.S., Ramalho A.C., Cavalcante T.A., Nery T.F.L. \& Guerra R.R. 2016. Descrição morfológica de duas espécies de Sapajus encontradas na Paraíba. Pesq. Vet. Bras. 36:317-321.

Breseida D.R. \& Ottoni E.B. 2001. Observational learning in the manipulation of a problem-box by tufted capuchin monkeys (Cebus apella). Revta Etologia 3:3-13.

Fragaszy D.M., Visalberghi E. \& Fedigan L.M. 2004. The Complete Capuchin: the biology of the genus Cebus. Cambridge University Press, Cambridge. 356p.

Gray H. 2000. Anatomy of Human Body. Bartleby Com., Philadelphia. 1600p.

Guimarães G.C., Machado M.R.F., Santos A.L.Q., Vieira L.G., Souza A.G., Silva J. M.M. \& Kaminishi Á.P.S. 2005. Origem e distribuição do nervo isquiáti- co no gato doméstico (Felis catus domesticus Linnaeus, 1758). Bioscience J. 21:189-195.

Lima M.O., Vieira L.G., Ribeiro P.R.Q., Sousa G.C., Silva Z., Silva D.C.O. \& Barros R.A.C. 2013. Morfologia dos músculos do ombro de Sapajus apella (Primates: Cebidae). Biotemas 26:129-135.

Lima A.R., Guimarães S.B., Branco E., Giese E.G., Muniz J.A.P.C., Ricci R.E.G. \& Miglino M.A. 2016. Anatomia e histologia do trato urinário do macaco-prego (Sapajus apella). Pesq. Vet. Bras. 3:221-226.

Lynch-Alfaro J.W., Matthews L., Boyette A.H., MacFarlan S.J., Phillips K.A., Falotico T., Ottoni E., Verderane M., Izar P., Schulte M., Melin A., Fedigan L., Janson C. \& Alfaro M.E. 2012a. Anointing variation across wild capuchin populations: a review of material preferences, bout frequency and sociality of anointing in Cebus and Sapajus. Am. J. Primatol. 74:299-314.

Lynch-Alfaro J.W., Silva J.R. \& Rylands A.B. 2012b. How different are robust and gracile capuchin monkeys? An argument for the use of Sapajus and Cebus. Am. J. Primatol. 74:273-286.

Lynch-Alfaro J.W., Izar P. \& Ferreira R.G. 2014. Capuchin monkey research priorities and urgent issues. Am. J. Primatol. 76:705-720.

Lopes R.J. 2004. Gênio da selva. Scient. American Brasil 3:24-32.

Marin K.A., Silva C.F.O., Carvalho V.A.A., Nascimento L.G.N., Prado L.Y.C. \& Aversi-Ferreira T.A. 2009. Anatomy of the nervous of forearm and hand of Cebus libidinosus (Rylands, 2000). Int. J. Morphol. 27:635-642.

Meulman E.J.M., Sanz C.M., Visalberghi E. \& Van Schaik C.P. 2012. The role of terrestriality in promoting primate technology. Evolutionary Anthropology 21:58-68.

Pereira K.F., Paranaiba J.F.F.S., Helrigle C. \& Araújo E.G. 2011. Origem e distribuição anatômica do nervo isquiático de mão-pelada. Pesq. Vet. Bras. 31:74-78.

Pereira K.F., Menezes V.A. \& Araújo E.G. 2013. Anatomia comparativa da dura-máter de Sapajus libidinosus. Pesq. Vet. Bras. 33:1263-1268.

Resende B.D. \& Ottoni E.B. 2002. Brincadeira e aprendizagem do uso de ferramentas em macacos-prego (Cebus apella). Estudos de Psicologia 7:173-180.

Rylands A.B., Schneider H., Langguth A., Mittermeier R.A., Groves C.P. \& Rodrigue-Luna E. 2000. An assessment of the diversity of new world primatas. Neotropical Primates 8:61-93.

Soares N.P., Vieira V. S, Carneiro-e-Silva F.O, Araújo E.G. \& Pereira K.F. 2014. Músculos da região perineal do macaco-prego (Sapajus libidinosus). Arqs MUDI 18:39-48.

Swindler D.R. \& Wood C.D. 1973. An Atlas of Primate Gross Anatomy. University of Washington Press, Washington. 370p.

Vieira V.S. 2013. Estudo anatômico comparativo dos músculos da coxa de Cebus spp. (Erxleben, 1777; Primates, Cebidae). Dissertação de Mestrado, Universidade Federal de Uberlândia, Uberlândia, Minas Gerais.

Vieira V. S., Soares N. P., Carneiro-e-Silva F.O., Lima F.C. \& Pereira K.F. 2015. Comparative anatomical study of the thigh muscles of Sapajus spp. (Primates, Cebidae). Enciclopédia Biosfera 11:579-592.

Vilanova R., Silva Junior J.S., Grelle C.E.V. \& Cerqueira G.M.R. 2005. Limites climáticos e vegetacionais das distribuições de Cebus nigritus e Cebus robustus (Cebinae, Platyrrhini). Neotropical Primates 13:14-19.

Waal F.B.M. 2005. Como os animais fazem negócios. Scient. American Brasil 4:68-75.

Wright K. A., Wright B.W., Ford S.M., Fragaszy D., Izar P., Norconk M., Masterson T., Hobbs D.G., Alfaro M.E. \& Lynch Alfaro J.W. 2014. The effects of ecology and evolutionary history on robust capuchin morphological diversity. Mol. Phylogenetics and Evolution 82:455-466. 